\title{
From interacting systems to a system of divisions
}

\author{
Stoetzler, Marcel
}

\section{European Journal of Social Theory}

DOI:

$10.1177 / 1368431016647970$

Published: 01/11/2017

Peer reviewed version

Cyswllt i'r cyhoeddiad / Link to publication

Dyfyniad o'r fersiwn a gyhoeddwyd / Citation for published version (APA):

Stoetzler, M. (2017). From interacting systems to a system of divisions: The concept of society and the 'mutual constitution' of intersecting social divisions. European Journal of Social Theory, 20(4), 455-472. https://doi.org/10.1177/1368431016647970

\footnotetext{
Hawliau Cyffredinol / General rights

Copyright and moral rights for the publications made accessible in the public portal are retained by the authors and/or other copyright owners and it is a condition of accessing publications that users recognise and abide by the legal requirements associated with these rights.

- Users may download and print one copy of any publication from the public portal for the purpose of private study or research.

- You may not further distribute the material or use it for any profit-making activity or commercial gain

- You may freely distribute the URL identifying the publication in the public portal ?
}

Take down policy

If you believe that this document breaches copyright please contact us providing details, and we will remove access to the work immediately and investigate your claim. 
From interacting systems to a system of divisions: the concept of society and the 'mutual $\underline{\text { constitution' of intersecting social divisions }}$

\begin{abstract}
This article examines a fundamental theoretical aspect of the discourse on 'intersectionality' in feminist and anti-racist social theory, namely the question whether intersecting social divisions including those of sex, gender, race, class and sexuality are interacting but independent entities with autonomous ontological bases or whether they are different dimensions of the same social system that lack separate social ontologies and constitute each other. Based on a historical reconstruction of its genesis, the article frames this as a dispute between system-theoretical and dialectical, 'Critical Theory'related approaches and argues that the latter better capture the dynamics of contemporary society including the perspective of its transcendence.
\end{abstract}

The discourse on intersectionality is 'a critique of solipsism, tokenism, and exclusion in both white-dominated feminist political discourses and male-dominated antiracist ones (such as Black nationalism)' (Carastathis 2014:313). The term was first introduced by Kimberlé Crenshaw (Crenshaw 1989; 1991) and is now a much celebrated 'buzzword' (Davis 2008). Rather than providing a general discussion of the concept, this article explores one particular theoretical aspect of 'intersectionality': are the intersecting social spheres or divisions understood to be autonomous, parallel interactors or mutually constitutive of each other? Taking my cue from Gudrun-Axeli Knapp's exhortation to the 'time-consuming activity' of 'reclaiming baggage' as against 'the speedy economy of doxographic mentioning' (Knapp 2005: 261), I will relate this theoretical aspect of the discourse on 'intersectionality' to earlier debates in feminist theory on race, class, sexuality and gender in the hope that revisiting the discussions out of which 'intersectionality' emerged in the first place may help illuminating some of its arguably still unresolved problems. Against recent suggestions by Sylvia Walby and others to abandon the idea of the 'mutual constitution' of social divisions I will try to develop Knapp's attempt to rearticulate intersectionality from the perspective of 'Frankfurt School' Critical Theory and maintain the notion of 'mutual constitution'. I suggest that the concept of society as a 'totality' of social mediations (pace Adorno) increases the critical purchase of the concept of intersectionality by strengthening the sense that different social divisions are mutually constitutive dimensions of the same societal constellation, rather than ontologically distinct but interacting 'systems'. 


\section{KIMBERLÉ CRENSHAW'S CONCEPT OF 'INTERSECTIONALITY'}

Crenshaw addressed in a now canonical article of 1989 'the tendency to treat race and gender as mutually exclusive categories of experience and analysis' (Crenshaw 1989: 139). Her starting point was an account of the different ways in which Black women experience discrimination: sometimes 'in ways similar to white women's experiences', sometimes similar to those of Black men, often though 'they experience double-discrimination - the combined effects of practices which discriminate on the basis of race, and on the basis of sex', and sometimes, and here is the rub, 'they experience discrimination as Black women not the sum of race and sex discrimination, but as Black women' (Crenshaw 1989: 149). It is this last case that, so the argument goes, has tended to escape the attention of researchers and activists, and this is where 'intersectionality' is most relevant. The term first occurs in this sentence:

Because the intersectional experience is greater than the sum of racism and sexism, any analysis that does not take intersectionality into account cannot sufficiently address the particular manner in which Black women are subordinated (Crenshaw 1989: 140).

Crenshaw uses the 1851 speech by Sojourner Truth, 'Ain't I a Woman?', an iconic text in the feminist tradition, to make the point that white women need to sacrifice 'racial privilege' to make the category 'woman' more comprehensive, and thus 'strengthen feminism' (Crenshaw 1989: 153): Sojourner Truth's speech challenged (white, upper or middle class) male mythology of femininity by pointing out that she who had 'ploughed and planted and gathered into barns' was anything but the delicate, weak creature that (white, upper or middle class) men professed to imagine women were. And yet, the fact that she quite obviously was a woman could not be denied even by those holding (in more or less bad faith) the mythological idea of delicate femaleness. (White, upper or middle class) men could maintain the myth of frail femininity, on the basis of which they tried to exclude women from the arduous tasks of making politics and history, only as long as (white, upper or middle class) women as well as men excluded black women like Truth from that category. ${ }^{1}$ Crenshaw concludes from this that racism and sexism sometimes destabilize each other: 
Black men and women live in a society that creates sex-based norms and expectations which racism operates simultaneously to deny; Black men are not viewed as powerful, nor are Black women seen as passive (Crenshaw 1989: 155).

In a related article from 1991, Crenshaw asserts that intersectionality is a reality on the level of lived experience (which she refers to as 'structural intersectionality') that ought to be reflected on the levels of feminist and anti-racist political practice ('political intersectionality'). She also discusses as a separate category 'representational intersectionality' that partakes in either, to the extent that 'representations' - her examples include lyrics of popular music and TV comedy routines - are elements of the reality that individuals (as consumers) are confronted with, while for their authors (the artists and writers) they constitute practical forms of (cultural, representational) politics. Her chief objection to 'vulgar constructionism' is that it fails to distinguish the power that is 'exercised simply through the process of categorization' from the power 'to cause that categorization to have social and material consequences' (Crenshaw 1991: 1297): for a social-scientific perspective, the issue is not 'difference' in itself but what difference any particular difference makes, and why it does so. The issue is the societal meaning and function of any specific difference (Crenshaw 1991: 1299). For Crenshaw, the discussion of intersectionality 'provides a basis for reconceptualising race as a coalition between men and women of color' by calling 'attention to how the identity of "the group" has been centered on the intersectional identities of a few' (Crenshaw 1991: 1299).

Powerful though it is, the image of the intersection is open to the important objection that it reifies and essentializes the social divisions that 'meet' or cross-cut in the intersection, evoking the notion that they are in fact different entities with their own (social) ontologies. This question has been articulated as the question whether the intersecting divisions are 'mutually constitutive' or ontologically independent from each other. This particular theoretical aspect is what interests me in the present context.

\section{THE EMERGENCE OF THE DISCOURSE ON INTERSECTIONALITY IN 1970s /1980s SOCIALIST-FEMINIST DEBATES}

Concepts are 'shorthand' for the process that produced them (Adorno 1989: 267), so that theoretical decoding and critique of a concept must include writing its history: deciphering 
'intersectionality' requires at least a partial reconstruction of its emergence. Patricia Hill Collins noted that it is rather 'ironic' that 'narratives of the emergence of intersectionality rarely include [the] period of social movement politics' but 'instead confine themselves to locating a point of origin when academics first noticed, named and legitimized this emerging field of study' (Collins quoted in Gines 2014: 13): 'For me, the 1970s and 1980s were the heady days of intersectional scholarship' as in those days the debates were about 'significant social issues'. Collins suggests that Crenshaw's 1991 article 'can also be interpreted as launching a decade where the initial vision of intersectionality became increasingly drowned out' (Collins quoted in Carastathis, 2014: 312).

As suggested by these remarks by Collins, the contemporary concept of intersectionality emerged from a broad variety of feminist discussions in the 1970s and 1980s that were anchored in anti-systemic social movements of the time and often reflected versions of Marxist and critical theory. In those 'heady days', questions of power, domination and exploitation were central, and the debate was not organised around one single metaphor such as intersectionality. Discussions at that time gave significant attention to the question whether social divisions mutually constitute each other or are ontologically separate entities.

Since the immediate post-WW2 period a 'triple jeopardy' approach to class, race and gender had developed that explored 'how, with the addition of each new category of inequality, the individual becomes more vulnerable, more marginalized, and more subordinate'. This approach was gradually replaced by an alternative one that focused on 'how race, class and gender interact' (Davis 2008: 71). Many commentators name as one of the most influential articulations of this alternative approach the 1977 'Black Feminist Statement' by the Combahee River Collective (a feminist group in Boston) that pointed 'to the futility of privileging a single dimension of experience as if it constituted the whole of life' (Brah and Phoenix 2004: 78) and argued that 'the major systems of oppression' - 'racial, sexual, heterosexual, and class oppression' - 'are interlocking' (Combahee River Collective 1981 [1977]: 210):

The synthesis of these oppressions creates the conditions of our lives. ... We also often find it difficult to separate race from class from sex oppression because in our lives they are most often experienced simultaneously. We know that there is such a thing as racial-sexual oppression which is neither solely racial nor solely sexual (Combahee River Collective 1981 [1977]: 210; 213). 
The significance of this statement and others that followed it can best be understood by looking at the context against which it was formulated. Probably the most canonical reference for an early formulation of the 'additive' or 'triple oppression' mode of accounting for intersections is the 1949 text by Claudia Jones, 'An End to the Neglect of the Problems of the Negro Woman!' (Boyce Davies 2008: 30). Jones, who was a leading figure in the Communist Party of the USA, stated that 'Negro women - as workers, as Negroes, and as women - are the most oppressed stratum of the whole population' (Jones 1949: 4). ${ }^{2}$ Jones rejected mainstream feminism ('the rotten bourgeois notion about a "battle of the sexes"') (Jones 1949: 13) while targeting 'white chauvinism ... in progressive circles' (Jones 1949: 12) especially that directed against Black women. She argues the Black 'national liberation' movement's 'proletarian leadership' will contribute to 'the achievement of a Socialist America' which alone is 'the final and full guarantee of woman's emancipation' (Jones 1949: 15-6). 'For the progressive women's movement, the Negro woman, who combines in her status the worker, the Negro, and the woman, is the vital link to this heightened political consciousness.' The thrust of Jones' text is the emphasis on the strategic importance of Black working class women for a Black nationalism that is expected to bring about 'Socialist America', implying that increased participation of Black working class women could help turning Black nationalism into a force for socialism, while women's emancipation in turn depended on the latter. The strategic meaning of the text is twofold: it challenges male and white patronising of women within the Communist Party and other progressive organisations, and supports this challenge by underscoring the (desirability of the) centrality of Black working class women for the party's 'anti-imperialist' strategy, including its reliance on Black nationalism. The rather mechanistic logic of the argument that 'triply oppressed' means 'most oppressed' as well as 'most central to revolutionary change' had lost much of its plausibility by the time the women of the Combahee River Collective were writing, ${ }^{3}$ although the latter (and those who followed them) built on the overall achievements of Jones and her comrades.

As acknowledged by Davis (2008), another pioneering text of what subsequently became the 'intersectionality’ discourse was the 1983 article by Floya Anthias and Nira Yuval-Davis, 'Contextualising Feminism - Gender, Ethnic and Class Divisions'. Anthias and Yuval-Davis argued that 
[r]ace, gender and class cannot be tagged on to each other mechanically for, as concrete social relations, they are enmeshed in each other and the particular intersections involved produce specific effects. The need for the study of the intersection of these divisions has been recognized recently by black feminists (Anthias and Yuval-Davis 1983: 62-3).

They write that within concrete class groupings at times 'there may be a coincidence of class and gender or ethnic position (and at other times there may be cross cuttings)', a perspective that recalls Georg Simmel's distinction between concentric and non-concentric circles (Simmel 1992: 472). For example, 'some fractions of the working class may be primarily composed of women or black people' (Anthias and Yuval-Davis 1983: 65). Crucial to Anthias' and Yuval-Davis' argument is that '[e]ach division presents ideological and organizational principles within which the others operate, although in different historical contexts and different social arenas their role will differ' (Anthias and Yuval-Davis 1983: 68): for example, 'ethnically specific definitions of women's and men's roles underlie the sexual division of labour in the family.' Conversely, in many contexts 'the interests of the nation or the ethnic group are seen as those of its male subjects', while 'the interests of "the state" are endowed with those of a male ethnic class and not just a class which is "neutral" in terms of ethnicity and gender'. However, women tend to be complicit in the maintenance of this situation: "very often women participate directly in the power struggle between their ethnic collectivity and other collectivities and the state' (Anthias and Yuval-Davis 1983: 71). The emphasis on the fact that each social division is constructed inside all others respectively adds significant complexity to the account of the intersections of social circles and is crucial to this early statement of the new paradigm. Kathy Davis writes that in the progressing development of the discourse on race, class, gender and sexuality more and more often interaction, sometimes mutual constitution of these categories was emphasised, not just their intersection as such (Davis 2008: 71). ${ }^{4}$

A more comprehensive genealogy of the intersectionality discourse would need to take into account also other theoretical developments of this period. Bilge for example points out that Stuart Hall's Althusser-derived concept of 'articulation' resembles that of the 'mutual constitution' in intersectionality discourses. Hall argued in 1989 in one of his best known essays, 'New Ethnicities', that 'the central questions around race have always appeared historically in articulation, in formation with other categories and divisions, and that they 
have never ceased to cross and re-cross categories of class, gender and ethnicity' (Hall cited in Bilge 2010, pp. 67-8). Hall echoed here a tradition of Althusser- and Lacan-influenced 'socialist feminism' that emerged in the early 1970s in the UK and began exploring 'how racial, class and sex ideology interlock' (Magaš 1971: 87). ${ }^{5}$ From a similar, more Foucaultinflected perspective (writing in the USA), Judith Butler stated in her 1990 book, Gender Trouble, that 'gender intersects with racial, class, ethnic, sexual, and regional modalities of discursively constituted identities' and that it is 'impossible to separate out "gender" from the political and cultural intersections in which it is invariably produced and maintained' (Butler 1990: 3). From within an Australian context, Jan Pettman wrote in 1991 that 'an additive model' fails to 'account for the dynamic interaction between different forms of oppression': 'Aboriginal women experience racism differently from Aboriginal men and differently among themselves, depending on age, class, disability and place of residence' (Pettman 1991: 188). The problem has not withered away with the last century: as Yuval-Davis observed in an article written more than twenty years after 'Contextualising Feminism', 'the question of whether to interpret the intersectionality of social divisions as an additive or as a constitutive process is still central' (Yuval-Davis 2006: 195).

\section{THE SYSTEM-THEORETICAL REJECTION OF THE NOTION OF THE MUTUAL CONSTITUTION OF SOCIAL DIVISIONS}

The question what exactly the closely related images of 'intersection', 'interlocking' or 'interaction' mean is at the heart of the wider intersectionality discourse, and it is crucial here to ask what exactly it means to say that the intersecting or interlocking categories, groups or circles 'constitute each other'. A recent contribution by Sylvia Walby, Jo Armstrong and Sofia Strid rejects the concept of 'mutual constitution' as too strong and argues that a weaker formulation such as 'mutual shaping' captures better what happens in the 'intersection' (Walby, Armstrong and Strid 2012: 235). Likewise, Walby had pointed earlier to a logical inconsistency in those versions of the 'intersectionality' theorem that emphasise the 'different ontological basis' of each social division or category: '[s]ince each category has a separate ontological base, how can they, in theory, mutually constitute each other?' (Walby 2007: 453). The question, how and to what extent social divisions and categories 'constitute' or merely 'shape' each other is in this way linked to the further question, what 'ontological basis' actually means: is it possible to argue, as feminist intersectionality theorists typically 
do, that social divisions or categories (or circles) are 'ontologically' irreducible to each other but at the same time mutually constitutive in the sense that the meaning, nature or essence of each one of them is dependent on all the others? This question pushes the discussion towards a more fundamental problem in social theory - namely the concept of society and its ontological status which I will discuss later on in this article.

Walby's proposition is to emphasise the 'full ontological depth' of each separate 'system' of oppression and division, and to weaken the 'mutual constitution' argument to saying that the 'systems' only partly, and not always, 'constitute' each other. It follows from her previous position within feminist theory as a proponent of 'dual systems' theorizing of class and gender (Walby 1986; 1989; 1990). Feminist 'dual systems' theory was a predominant position within feminist discussions on how theoretically to interrelate capitalism and patriarchy, and, respectively, socialism and feminism, in the 1970s and 1980s. ${ }^{6}$ As the contributions to this debate on 'socialist feminism' often, although by no means always, also included race and sexuality as categories to be interrelated with class and sex (and/or gender), they can be considered the main body of theoretical literature out of which the intersectionality discourse on the 'mutual constitution' of social divisions emerged. $^{7}$

Walby's 2007 proposition is based on a version of systems theory 'hybridized' by introducing 'complexity theory' (Walby 2007: 458). She defines 'each set of social relations (e.g. gender, ethnicity, class)' as 'a system, taking all others as its environment' (Walby 2007: 458). The relationship between systems can but must not be hierarchical. 'Systems are over-lapping and non-nested', i.e. 'one system is not necessarily wholly contained by another' (Walby 2007: 459). Furthermore, 'a system does not necessarily fully saturate the space or territory that it is in', such as an institution. Walby also suggests replacing the concept of 'society' by 'societalization' as 'society' is too much burdened with the traditional notion that 'a society' is the same as 'a nation state'. Against Walby, I would argue, though, that the concept of society is not necessarily equated with nation in all sociological traditions: the concept of society as 'societalisation' and the rejection of the identification of 'society' with 'nation' are also characteristics of Critical Theory (Adorno 1989; see below on this). 
Because the 'mutual constitution' problem in the contemporary 'intersectionality' discourse is inherited from earlier feminist debates on 'dual systems theory', revisiting the latter can help illuminating the former. The system-theoretical question whether there is one system with several sub-divisions, or several independent, but interacting systems, relies on the logically prior question how autonomous one understands the 'causal' or 'ontological' bases of the respective systems or subdivisions to be. The socialist-feminist debate in the late 1970s addressed whether contemporary society should be understood as one system comprising several integrated 'structures' including capitalism and patriarchy, or whether the latter (as well as, sometimes, racism or 'white supremacy') should be understood as autonomous, though interacting, systems in their own right. In an influential contribution to this debate, Nancy Hartsock stated - in terms of critique of the 'dual systems' approach - that 'each of the interlocking institutions of capitalism, patriarchy, and white supremacy conditions the others, but each can also be understood as a different expression of the same relations' (Hartsock 1979: 63):

Since each phenomenon changes form constantly as the social relations of which it is composed take on different meanings and forms, the possibility of understanding processes as they change depends on our grasp of their role in the social whole. ... As feminists, we begin from a position which understands that possibilities for change in any area are tied to change occurring in other areas (Hartsock 1979: 63).

This line of critique of 'dual systems theory' is not invalidated by either the addition of 'complexity theory' nor the addition of a third 'system' (or any number of additional systems). Anna Pollert (1996) suggested against Walby that conceiving of capitalism and patriarchy as parallel concepts supposedly representing parallel but interacting social systems or structures is 'unhelpful since the process of gendering takes place inside class relations' (Pollert 1996: 640). The notion of 'interaction' is misleading since it presupposes that the 'interactors' are essentially different entities. Pollert suggests instead that the 'two sets of relationships', class and gender, 'evoke two analytic levels ... for the purpose of explaining one system, not two' (Pollert 1996: 643; 647).

The critique of Walby's and others' commitment to a form of systems theory was an important strand in the formative stages of the intersectionality discourse. Anthias and YuvalDavis dedicated a section of their book Racialized Boundaries to the critique of the concept 
of patriarchy especially in Walby's (1990) conception of 'dual systems theory' (Anthias and Yuval-Davis 1993: 106-113). They argued against positing patriarchy 'as an independent system' as this tends to stand in the way of treating gender relations 'as outcomes of the interplay of social processes and social divisions more broadly conceived' (Anthias and Yuval-Davis 1993: 107), including the agency of women in their own subordination (Anthias and Yuval-Davis 1993: 108). They argued that 'although the discourses of racism and sexism are distinct', whereby gender 'relates to the binary social ontology of biological sexual difference' and racism 'to the social ontology of collectivity and belongingness', patriarchy or racism could not be seen as 'separate systems or structures of domination': 'class, gender and race ... are not manifestations of different types of social relations with distinct causal bases ... within distinct systems of domination' (Anthias and Yuval-Davis 1993: 109). Concerning class, they point to 'the formation of concrete classes involved in class struggle' as 'not only the product of processes endemic within the sphere of production' but 'historically constructed in relation to the divisions of gender and ethnos (including race)' (Anthias and Yuval-Davis 1993: 18). Concerning gender, Anthias and Yuval-Davis emphasise that 'the practices and representations around gender are themselves not the product of [the] difference' that these practices and representations gesture towards (the 'ontological base') 'but originate in social relations that include those of class and raceethnicity' (Anthias and Yuval-Davis 1993: 18). It is not spelt out here in what relationship 'ontological bases' stand to their respective 'representations', but it is implied that in societal reality race and gender are based on the claim that they have an ontological base. ${ }^{8}$ Anti-racist and-sexist strategies must therefore aim to undermine this claim, not to take it at face value.

The dual (or triple) systems debate amongst socialist feminists slowly and gradually mutated - driven by intensifying critique from Black feminists - into the 'intersectionality' discourse that from around 1990 achieved high credibility in academic as well as policy contexts. Contrasting answers to the question whether differing social circles, spheres or divisions are causally and ontologically autonomous 'systems' or different expressions of the same fundamental social structure continued to be given. In the following section of the article I will explore one particular strand of the contemporary debate, namely the proposition to think intersectionality through the eyes of Critical Theory. The principal argument here is that ethnic, race, class and gender relations have but one 'ontological base', namely society as a whole that produces and organizes the practices, structures, representations, ideologies and discourses that constitute them: societal totality, nothing less, nothing more, is their 
'ontological basis'. This totality can be conceived of as a 'being' or an 'essence' (an ōn as in ontology) only, though, in a very weak sense of the word, namely as a structured and dynamic set of relationships between individuals who are in turn constituted by it. This amounts to only a weak sense of societal 'ontology' - a minimal dose of Durkheimian 'thingism', as it were - that is central to a Critical Theory perspective (Adorno 1996).

\section{INTERSECTION, INVISIBILITY AND VERWERTUNGSLOGIK: THE CRITICAL THEORY-INFLECTED VERSION OF INTERSECTIONALITY}

In a recent contribution, Gudrun-Axeli Knapp (2010) argued that the discourse on intersectionality lacks a concept of society. Taking her cue from a formulation by Adorno, she emphasises that it is the 'societalising' operation of society - Vergesellschaftung - that produces societal spheres, separations, groups, categories, forms of subjectivity and their numerous and complex interrelations and intersections in the first place, and 'prior to all specific forms of stratification' (Adorno 1989: 271), i.e. logically prior to the more specific operations of class, ethnic, gender and other stratifications or differentiations (Knapp 2010: 230). ${ }^{9}$ Only the adoption of a concept of society and its reproduction through 'societalization' can distinguish the intersectional approach from merely another variety of stratification theory as categories are not necessarily groups (Knapp 2010: 224; Brubaker 2004). Knapp develops her conception of the on-going reconstitution of society through 'societalization' through a reading of the concept of 'invisibility' in intersectionality theory. She states that intersectionality theory distinguishes two forms of making invisible: on the one hand, members of a group who are considered not to be 'prototypical' (such as Black women when 'Blacks' are 'prototypically' presupposed to be male) tend to be 'intersectionally invisible', i.e. excluded from consideration, analysis or certain forms of institutional (e.g. legal) action (Knapp 2010: 225). On the other hand, though, also certain characteristics of the fully 'prototypical' members of that group - characteristics that are part of what makes these members 'prototypical' such as the maleness of male Black persons - can be 'intersectionally invisible': in that example, the maleness of the male Black person - insofar as he functions as representative or prototype of 'Blacks' - is invisible or forgotten.

Knapp relates the argument on invisibility (which she adopts from Crenshaw 2000) to other accounts of invisibilization in social theory. The example she uses stems from the critical theory of the family: 'in the course of the historical process by which the ideal of the 
breadwinner-plus-housewife-family became hegemonic and traditional, its bourgeois class origins [as well as its modernity] became invisible' (Knapp 2010: 232). Knapp refers to this process as a form of 'socially structured forgetting' and points out that the 'de-reifying critique' of such forgetting is central to those strands of feminist social theory that have maintained a relationship to 'the Marxian critique of political economy' (Knapp 2010: 233). The paradigmatic argument in this tradition is Marx's notion of 'the invisibilization of the non-contractual dimension of the exchange of equivalents on the market' that helps promote the 'meritocratic legitimization of inequality'. Knapp writes that 'invisibilization' is based on structured and institutionalized societal practices, including but not reducible to forms of consciousness (be it 'false' or not so 'false'). Knapp points out that in the Critical Theory especially of Horkheimer and Adorno such structured practices are theorized as 'the domination of the general over the specific' that 'emerges from non-intended, systemic effects of the acting of individuals' (Knapp 2010: 234). The 'particular dynamic' that drives modern society results from the 'capitalist logic of valorization' that has become autonomous from the actors, is irrational, crisis-ridden and 'cannot even be controlled by the ruling class'. The concept of 'logic of valorization' ('Verwertungslogik') refers to the defining characteristic of the capitalist mode of production - its 'logic', as it were - to produce commodities as 'values' in the sense of the word developed by classical political economy, namely possessing exchange-value in distinction from use-value, and to produce use-values only if and when they can be expected also to be lucrative exchange-values (i.e. to produce useful medicines, for example, only if and when they will generate a profit). The notion of a 'particular dynamic' consisting in 'the domination of the general over the specific' that is at the core of the concept of 'societalization' in Critical Theory distinguishes the latter from conceptions of society as 'systems of group-based hierarchies' that underlie some more positivistic strands of the discourse on intersectionality.

Although Knapp argues primarily from within the framework of Critical Theory, she also emphasizes its lack of attention to 'the historical mediation of patriarchalism/androcentrism with capitalism' and the role of gender relations for 'the processes of reproduction and transformation of the societal totality' (Knapp 2010: 235). Here is where the intersectionality discourse can make a significant contribution to further developing Critical Theory, as much as the latter can help illuminating some aspects of the former. 
Within a Critical Theory-inflected version of the 'intersectionality' framework, what actually happens in the intersections is understood to be determined by society. This throws up the question, what is society. I would like to propose, following Knapp following Adorno, a concept of society as the totality of structured practices that produce the social divisions, categories and groups that intersect and, in their intersections, mutually constitute each other. I would like to suggest that this concept of society allows for the formulation of a theory of intersectionality that accounts for not only the mere fact that differing societal divisions constitute each other, but also for the more tricky question, in what way they tend to do so, and whether any one of them is dominant over the others at any one point in time, and if so, then why and when. It is important to note that not all social divisions are equally relevant all the time; their relative relevance to each other shifts with the constellation in which they find themselves. The analysis of intersectionality based on the concept of society as a mediating totality would support what might be the most interesting area of further developing intersectionality theory, namely exploration of the question in which specific constellations divisions stabilize and assimilate each other mutually, and in which specific constellations they destabilize each other and provide space for anti-systemic agency. In other words, when do intersections point to cracks in the totality, and when are they its welding seams? From the perspective of a social theory based on a commitment to changing society in the direction of emancipation, the case of divisions contradicting each other and destabilizing the system arguably is the most interesting aspect of what Crenshaw described in her initial conception of intersectionality: 'Black men and women live in a society that creates sex-based norms and expectations which racism operates simultaneously to deny' as when 'Black men are not viewed as powerful, nor are Black women seen as passive' (Crenshaw 1989: 155). This is of course nothing other than the classic argument by Sojourner Truth who pointed to a systemic contradiction - a crack - that allowed a social movement to emerge: I differ in several important respects - just look at my biceps - from the concept of 'woman' that you, the (white, male, bourgeois-planter) society propagate, but ain't I a woman, nevertheless? The Marxian perspective that underlies Adorno's theorizing would point to the fact that it is the 'logic of valorization' of capitalist plantation slavery that allows Truth's biceps to destabilize the patriarchal idea of femininity: the cracks in the building of domination (Holloway 2010) are produced by the totalizing dynamic that this building itself rests upon and to which also 'the rulers' are subjected, forcing them to undermine their own (patriarchal) domination through their own (capitalist) economic activity. 


\section{THE FAMILY AS A CRACKING SITE}

It is perhaps no coincidence that Knapp chose the family as the example with which to explain the concept of 'invisibilization': one of the starting points of intersectional analysis amongst Black feminists, too, has been the issue of how to assess the family in the context of emancipation struggles. Angela Davis (1981) had observed that the role of 'mother/housewife' (even the word itself seems inappropriate) had a different meaning in the context of the slave community than elsewhere. Spelman commented:

The work of mate/mother/nurturer has a different meaning depending on whether it is contrasted to work which has high social value and ensures economic independence, or to labor which is forced, degrading and unpaid. All of these factors are left out in a simple additive analysis (Spelman 1982: 43).

In other words, it is wrong to claim schematically that a female, child-rearing slave was multiply oppressed, as the role of 'mate/mother/nurturer' in the slave family is a relatively powerful one when compared to that of the male slave, whereas the role of 'mate/mother/nurturer' in the family of the wage-working male breadwinner is relatively non-prestigious and subordinate. Spelman concluded, in an early example of intersectional analysis:

The family may be the locus of oppression for white middle-class women, but to claim that it is the locus of oppression for all women is to ignore the fact that for blacks in America the family has been a source of resistance against white oppression (ibid.: 58).

This intersectional analysis should not, however, be understood simply to mean that in one set of circumstances the family is 'the locus of oppression', while in another set of circumstances it is not. It seems more appropriate to say that the family (as a general social form) is - in all modern if not all contexts - typically both a locus of oppression and of resistance simultaneously. This was indeed one of the core findings of empirical research conducted by the Frankfurt Institute for Social Research (the initial institutional home of 'Frankfurt School' Critical Theory) in the years immediately preceding the Nazi takeover of 
power. Adorno later expressed this ambivalence of the family when he wrote that 'it sometimes seems as if the fatal germ-cell of [bourgeois] society, the family, were at the same time the nurturing germ-cell of uncompromising pursuit of the other', namely of the alternative, emancipated society (Adorno 2002: 22-3; 1994: 17; translation amended). Different historical-societal constellations differ in how this dialectic of the family that represses, but at the same time also shapes and strengthens the individual and his or her power to resist and fight for an alternative to oppressive society, plays out. ${ }^{10}$ The dialectical perspective of Critical Theory avoids the notion that there are 'types' of family that are either repressive or empowering. No such types exist in socio-historical reality. ${ }^{11}$

\section{ONCE THE TOTALITY IS GONE, INTERSECTIONAL DIVERSITY WILL CELEBRATE}

My principal proposition in this paper is that the (Marxian) concept of totality as it can be found in e.g. Adorno's Critical Theory provides the notion of the 'intersection' with a richer set of meanings than its more mainstream, less explicitly dialectical alternatives, and is also more consistent with the genealogy of the discourse on 'intersectionality'. The key term in Adorno's concept of society describing the workings of 'the totality' is that of 'societalization' (or 'sociation': 'Vergesellschaftung'), the constitution - by society - of the individual as subjected to society. Societalization produces in the individual the inner, functional (but more than merely functional) connectedness that constitutes 'society in the strong sense' of the word, or else, modern society (Adorno 2000: 29): society as denoting 'a certain kind of intertwinement which leaves nothing out' (Adorno 2000: 30) emerged only in the nineteenth century and differs decisively from earlier types of 'society' in the generic sense of the word (Adorno 1989; Benzer 2011, chapter 1).

This concept of society denotes society as a complex process of mediation that involves a variety of forms of structured forgetting. The latter are given their orientation - like so many compass needles - by the magnetic field of the predominance of the general over the specific: the 'totality', which in the context of Critical Theory denotes a mediated (opaque, non-overt) form of domination that it encourages individuals to overcome. In modern, as opposed to 'traditional' society, domination is not located opposite to and facing society but is inherent in all its constituent elements and dimensions: saying that societal totality 'is a category of mediation, not one of immediate domination and subjugation' means that it 'does not lead a life of its own over and above that which it unites and of which it, in turn, is 
composed' (Adorno 1976: 107). The perspective of switching off the magnet, as it were, becomes visible with the recognition that it does not reside somewhere outside or above society but down here: we individuals who constitute society are the totality, although not deliberately so. The mutual mediation, constitution and shaping of the 'moments' of society (a more open and fluid alternative to speaking of 'circles', 'spheres' or 'sub-systems') is what society is - mutual mediation is its essence or 'ontological base'. Short of speaking of 'systems', it is important to acknowledge the 'systemlike quality' of modern life (Postone 1993: 158) which is grounded 'in determinate forms of social practice', namely 'an abstract, homogeneous, and objectifying form of practice'. Historically specific 'forms of everyday practice' constitute 'the social world' (Postone 1993: 155). As agency is grounded in the 'moments' that in their interactions constitute the totality, this is also where changes in the totality emerge from. 'System' and practice reciprocally constitute each other in capitalist society. The central concern of Marxian dialectical theory is with how the 'laws of motion' of the capitalist mode of production are constituted by acting individuals (Postone 1993: 135), a concern that bears some resemblance to Pierre Bourdieu's concern with 'rules unknown to the agents' (Bourdieu 1977). Marx's focus is first of all on the most unavoidable and forcefully imposed set of such practices: 'Dealing with commodities on an everyday level ... involves ... a continuous act of abstraction' (Postone 1993: 175). The mentality that is produced by the endless stream of acts of exchange of equivalents (that are equivalents only in terms of exchange value) then radiates outward into increasingly more 'spheres' of interpersonal life, resulting in increasing totalization and closure of society - as well as precarious countertendencies that keep the totality, even in its most advanced state of closure, on its toes. 'Totality' in this sense is a specifically oppressive quality of contemporary capitalist society that emancipatory movements aim to abolish. In terms of intersectionality, the destruction of 'the totality' would mean that the number of possible intersectional subject positions would increase infinitely; social circles would become less and less concentric, their intersections more evenly distributed. The more liberated a society, the less belonging to one 'circle' or category would determine belonging to any others: with intersectionality, diversity would finally celebrate. ${ }^{12}$

I suggest in this sense to restate intersectionality theory with a Critical Theory bend to the effect that the specific form of all social divisions (spheres, circles, systems) has one shared determining 'ontological base', or 'cause', namely society in the sense of a mediating totality. ${ }^{13}$ This is in spite of the fact that these divisions themselves have historical cores that 
far predate capitalist modernity but are increasingly completely transformed by it: modern sexual division is not the same as medieval or ancient sexual division. All social divisions not merely 'shape' (as Walby and others suggest) but indeed constitute each other in the sense that society - the mediation by the societal totality - constitutes all of them simultaneously, as well as their interactions, intersections and contradictions to the extent even that the totality of their relations to other divisions has immigrated into their essence and is an intrinsic part of what they essentially are: each division is constituted by how it relates to all the others; as this totality can never be 'defined' - it is in practice infinite and always evolving - each division as such cannot be defined, either. What one is, suffers, belongs to, or longs to be, is multifaceted and contradictory. Longings and aversions are related to belongings in complicated and ambiguous ways: what social group or category one belongs to does not determine political or cultural values, goals or dreams. And yet: the former inform the latter, if only to the extent that one may not wish to remain tomorrow what one is today. Nor do one's positionings, situatedness and belongings simply add up to an 'identity' (a being so and not other) - as if my hold of 'ethnicity no. 7' plus 'gender no. 2' plus 'citizenship in state No. 11' etcetera could ever equate to exactly what 'I am'.14

Why does any of this matter? Thinking intersections, interactions, contradictions in the framework of the dialectical imagination points - through and against the experience of increasing totality - to a perspective beyond the closure of the world of 'either - or':

It is only when we examine identities as fields of intersections and therefore always of contestation that we can imagine possibilities other than the binaries of 'Are you with the besieged dictator or are you with the invading army?' It is possible to be neither (Sengupta 2006: 632).

Intersectional analysis assures us that it is possible to be neither; Critical Theory adds the normative claim that it is vital. The perspective of liberating diversity, the joyful multiplication of intersections, can only be formulated from the determined negation of the totality of identities - the matrix of all possible being-so's - beyond merely acknowledging their intersectionality.

\section{REFERENCES}


Adorno TW 1972 Gesellschaft (I). In: Gesammelte Schriften Band 8: Soziologische Schriften I. Frankfurt/Main: Suhrkamp, pp. 9-19.

Adorno TW 1976 On the Logic of the Social Sciences. In: Adorno, TW, H. Albert, R. Dahrendorf, J. Habermas, H. Pilot and KR Popper, The Positivist Dispute in German Sociology, Translated by Glyn Adey and David Frisby. London: Heinemann, pp. 105122.

Adorno TW 1989 Society. In: Bronner, SE and DM Kellner (eds.) Critical Theory and Society, A reader. New York/London: Routledge, pp. 267-275.

Adorno TW 1994 Minima Moralia, Reflexionen aus dem beschädigten Leben, Frankfurt/M: Suhrkamp.

Adorno TW 1996 Einleitung zu Emile Durkheim, Soziologie und Philosophie. In:

Gesammelte Schriften Bd. 8, Soziologische Schriften. Frankfurt/M: Suhrkamp, pp. 24578.

Adorno TW 2000 Introduction to Sociology. Cambridge: Polity.

Adorno TW 2002 Minima Moralia, Reflections from Damaged Life, London: Verso.

Anthias, F and N Yuval-Davis 1983 Contextualising Feminism - Gender, Ethnic and Class

Divisions. In: Feminist Review 15: 62-74.

Anthias, F, and N Yuval-Davis 1993 Racialized Boundaries. London: Routledge.

Benzer, M 2011 The Sociology of Theodor Adorno. Cambridge, New York: Cambridge University Press.

Bilge, S 2010 Recent Feminist Outlooks on Intersectionality. In: Diogenes 225: 58-72.

Bottomley, G, M de Lepervanche and J Martin, eds. 1991 Intersexions.

Gender/class/culture/ethnicity. Sydney: Allen \& Unwin.

Bourdieu, P 1977 Outline of a Theory of Practice. Cambridge: Cambridge University Press. Boyce Davies, C 2008 Left of Karl Marx. The Political Life of Black Communist Claudia Jones. Durham, NC: Duke UP.

Boyce Davies C 2011 Claudia Jones. Beyond Containment. Autobiographical Reflections, Essays and Poems. Banbury: Ayebia Clark.

Brah A and A Phoenix 2004 Ain't I a Woman? Revisiting Intersectionality. Journal of International Women's Studies 5(3): 75-86.

Brubaker R 2004 Ethnicity without Groups. Cambridge, Mass: Harvard University Press. Butler, J 1990 Gender Trouble. Feminism and the Subversion of Identity. London: Routledge. 
Cambridge, AX 2011 When Socialist Values Harmonise with Human Desire for Liberation: Assessing Claudia Jones’ Politics. In: Boyce Davies 2011, pp. 207-20.

Carastathis, A 2014 The Concept of Intersectionality in Feminist Theory. Philosophy Compass 9(5): 304-14.

Carson, J 1998 (Re)viewing Mary Kelly’s Post Partum Document. In: Documents 13, pp. 4160.

Collins, PH 2012 Looking Back, Moving Ahead: Scholarship in Service to Social Justice. Gender and Society 26(1): 14-22.

Collins, PH 1991 [1990]_Black Feminist Thought. Knowledge, Consciousness and the Politics of Empowerment. New York: Routledge.

Combahee River Collective 1981 [1977] A Black Feminist Statement. In: Moraga, C and G Anzaldúa, eds. This Bridge Called My Back: Writings by Radical Women of Color. Watertown: Persephone Press, pp. 210-218.

Crenshaw, K 1989 Demarginalizing the Intersection of Race and Sex: A Black Feminist Critique of Antidiscrimination Doctrine, Feminist Theory and Antiracist Politics. The University of Chicago Legal Forum Volume 1989, Feminism in the Law: Theory, Practice and Criticism, 139-67.

Crenshaw, K 1991 Mapping the Margins: Intersectionality, Identity Politics, and Violence against Women of Color. Stanford Law Review 43(6): 1241-99.

Crenshaw K 2000 Gender-Related Aspects of Race Discrimination. Background paper for the expert meeting on the gender-related aspects of race discrimination November 21-24, 2000, Zagreb, Croatia. Accessed 22 April 2013. http://www.scribd.com/doc/59911382/Background-Paper-for-Expert-Meeting-onGender-Related-Aspects-of-Race-Discrimination-WCAR-Crenshaw.

Davis A 1981 Women, Race, and Class. New York: Random House.

Davis K 2008 Intersectionality as buzzword, A sociology of science perspective on what makes a feminist theory successful. Feminist Theory 9(1): 67-85.

Eisenstein, ZR, ed. 1979 Capitalist Patriarchy and the Case for Socialist Feminism. New York and London: Monthly Review Press.

Eisenstein, Z 1979 Some Notes on the Relations of Capitalist Patriarchy. In: Eisenstein ZR, ed., Capitalist Patriarchy and the Case for Socialist Feminism. New York and London: Monthly Review Press, pp. 41-55. 
Gines, KT 2014 Race women, race men and early expressions of proto-intersectionality, 1830s-1930s. In: Goswami N; M O’Donovan, L Yount, eds., Why Race and Gender still matter: An intersectional Approach. London: Pickering and Chatto, pp. 13-25.

Glenn EN 1985 Racial Ethnic Women's Labor: The Intersection of Race, Gender and Class Oppression. Review of Radical Political Economics 17:3: 86-108.

Guidroz, K and MT Berger 2009 A Conversation with Founding Scholars of Intersectionality, Kimberlé Crenshaw, Nira Yuval-Davis, and Michelle Fine. In: Berger and Guidroz (eds.) The Intersectional Approach, Transforming the Academy through Race, Class, and Gender. Chapel Hill: The University of North Carolina Press, pp. 61-78.

Gunnarsson L 2015 Why we keep separating the "inseparable": Dialecticizing intersectionality. European Journal of Women's Studies (online first).

Hall, S 1992 [1989] New ethnicities. In: Donald J and Rattansi A (eds.) Race, Culture and Difference. London: Sage, pp. 252-9.

Hartmann H (1981) The Unhappy Marriage of Marxism and Feminism: Towards a more progressive union. In: Sargent L (ed.) (1981), pp. 1-41.

Hartsock N 1979 Feminist Theory and the Development of Revolutionary Strategy. In:

Eisenstein ZR, ed., Capitalist Patriarchy and the Case for Socialist Feminism. New York and London: Monthly Review Press, pp. 56-77.

Holloway J 2010 Crack capitalism. London: Pluto Press.

Hooks, b (G Watkins) 1981 Ain't I A Woman. black women and feminism. Boston: South End Press.

Jones C 1949 An End to the Neglect of the Problems of the Negro Woman! In: Political Affairs (June 1949) [Republished as a pamphlet by National Women's Commission, C.P.U.S.A.] (also available in C Boyce Davies, 2011, pp. 74-86).

Joseph G (1981) The incompatible ménage à trois: Marxism, Feminism, and Racism. In: Sargent L (ed.) (1981), pp. 91-107.

Kelly M (1970) Women's Liberation and National Liberation. Shrew, Special Double Issue 2/-.

Knapp G-A (2005) Race, Class, Gender. Reclaiming Baggage in Fast Travelling Theories. European Journal of Women's Studies 12(3): 249-65.

Knapp G-Ai (2010) 'Intersectional Invisibility’: Anknüpfungen und Rückfragen an ein Konzept der Intersektionalitätsforschung. In: Lutz H; MTH Vivar; L Supik (eds.) Fokus 
Intersektionalität, Bewegungen und Verortungen eines vielschichtigen Konzeptes.

Wiesbaden: VS Verlag, pp. 223-243.

Lynn D (2014). Socialist Feminism and Triple Oppression. Claudia Jones and African

American Women in American Communism. Journal for the Study of Radicalism 8:2: 120 .

Magaš B (1971) Sex Politics: Class Politics. New Left Review 66: 69-96.

Pettman J (1991) Racism, sexism and sociology. in Bottomley G; M de Lepervanche and J

Martin (eds.) Intersexions. Gender/class/culture/ethnicity. Sydney: Allen \& Unwin, pp. 187-202.

Pollert A (1996) Gender and Class revisited; or: The Poverty of 'Patriarchy'. Sociology 30:639-59.

Postone M (1993) Time, Labor and Social Domination, A Reinterpretation of Marx's Critical Theory. Cambridge (Mass): Cambridge University Press.

Sargent L (ed.). (1981) Women and Revolution. The Unhappy Marriage of Marxism \& Feminism. A Debate on Class and Patriarchy. London: Pluto Press.

Sengupta S (2006) I/Me/Mine: Intersectional identities as negotiated minefields. Signs:

Journal of Women in Culture and Society 31(3): 629-39.

Simmel G (1992 [1908]). Soziologie. Untersuchungen über die Formen der

Vergesellschaftung, herausgegeben von Otthein Rammstedt, Gesamtausgabe Band 11.

Frankfurt/M: Suhrkamp.

Spelman EV (1982) Theories of Race and Gender: The Erasure of Black Women. Quest $5(4): 36-62$.

Stoetzler M (2016) Intersectional Individuality: Georg Simmel's Concept of “The Intersection of Social Circles" and the Emancipation of Women. Sociological Inquiry (early view).

Stoetzler M (2005) Subject Trouble: Judith Butler and Dialectics. Philosophy and Social Criticism 31(3): 343-69.

Truth S (1851) Ain't I a Woman? [http://www.fordham.edu/halsall/mod/sojtruthwoman.asp.] (Accessed 18 April 2013).

Walby S (1986) Patriarchy at work: patriarchal and capitalist relations in employment.

Cambridge: Polity.

Walby S (1989) Theorising Patriarchy. Sociology 23(2): 213-34.

Walby S (1990) Theorizing Patriarchy. Oxford: Blackwell. 
Walby S (2007) Complexity Theory, Systems Theory, and Multiple Intersecting Social Inequalities. Philosophy of the Social Sciences 37(4): 449-70.

Walby S; J Armstrong; S Strid (2012). Intersectionality: Multiple Inequalities in Social Theory. Sociology 46(2): 224-40.

Young I (1981) Beyond the unhappy marriage: A critique of the dual systems theory. In:

Sargent L (ed.) (1981), pp. 43-69.

Yuval-Davis N (2006). Intersectionality and Feminist Politics. European Journal of Women's Studies 13(3): 193-209.

\footnotetext{
${ }^{1}$ Truth's argument is for making the category of 'woman' more realistic and more inclusive, not, as has sometimes been argued (e.g. Brah and Phoenix 2004: 77), for deconstructing it. 2 Jones was ordered to be deported from the USA in 1951 and came to the UK in 1955 after her native Trinidad refused her entry. In the UK, too, she remained a key figure in anti-racist struggles. She died at 49 in 1964 due to health issues that had been acerbated by several prison spells in the USA between 1948 and 1955 (Boyce Davies 2008). Jones did not actually coin the term 'triple oppression' (sometimes, 'triple exploitation'): it was coined by Louise
} Thompson, another prominent Black woman in the CPUSA (Lynn 2014: 6).

${ }^{3}$ Jones held the Leninist 'anti-imperialist' position on the 'self-determination of nations' (Cambridge 2011) and was instrumental in 1946 to popularize within the CPUSA the positon the COMINTERN had taken since 1928 that the Black Americans of the 'black belt' constituted a colonized nation, and their struggle a national liberation struggle (Lynn 2014: 910). This gave legitimacy to Black nationalism within the $\mathrm{CP}$ and was a precondition of the emergence of the 'triple oppression' discourse.

4 'Mutual constitution' was part of the discourse already at an early stage, though: in a paper from 1972, Pat Armstrong had already made this type of argument, using a different metaphor, 'circumscription': 'White women must realize that as womanness circumscribes their whiteness (they are not white males), so their whiteness circumscribes their womanness' (quoted in Joseph 1981: 102). Joseph quotes from an unpublished 1972 conference paper. The earliest book-length discussion of intersectionality avant la lettre was probably bell hooks (1981). She clearly names the starting point: 'All too frequently in the women's movement it was assumed ... that identifying oneself as oppressed freed one from being an oppressor' (hooks 1981, 8-9). White feminists failed to understand 'their own sexist-racist 
attitudes toward black women' (ibid., 9). An interesting early text on the subject matter that actually has 'intersection' in the title is Glenn (1985).

${ }^{5}$ Magaš points here to the feminist journal Shrew and in particular to a 1970 article by the conceptual artist Mary Kelly (Kelly 1970). On Kelly, see Carson 1998.

${ }^{6}$ Iris Young, in a critique of an article by Heidi Hartmann, at the time probably the best known proponent of 'dual systems theory', stated that 'the majority of socialist feminists espouse some version of the dual systems theory' (Young 1981: 44).

${ }^{7}$ Zillah Eisenstein stated in her chapter, 'Some Notes on the Relations of Capitalist Patriarchy', that her aim was 'to understand the points of contact between patriarchal and class history and to explicate the dialectic between sex and class, sex and race, race and class, and sex, race, and class' (Eisenstein 1979b: 42). Sexuality is mentioned earlier on the same page, too. Yuval-Davis, though, recalls the following: 'Unlike in the United States [and in Israel], Marxist sociology was very popular in Britain, so discussing the interrelationship of gender and class was widely acceptable. But the minute some of us tried to introduce the interrelationships of gender to race and ethnicity, the eyes of many women in our group became glazed, as it was then considered by most socialist feminists to be only of marginal interest and relevant only to a small minority of women' (Yuval-Davis as quoted in Guidroz and Berger, 2009: 68).

${ }^{8}$ Anthias and Yuval-Davis sometimes imply that class actually has an 'ontological base', namely the 'production processes' that produce class divisions whose articulation as 'concrete classes' is shaped by concrete struggles that are in turn shaped by diverse variables including race and gender relations which are 'ideological': 'they do not have a basis in reproduction, but reproduction is represented as their basis' (Anthias and Yuval-Davis 1983: 66). 'Ethnic' phenomena' are 'forms of ideological construct which divide people into different collectivities or communities' (Anthias and Yuval-Davis 1983: 66).

${ }^{9}$ Knapp quotes from the following sentence by Adorno: 'Above and beyond any specific stratification, the abstractness of exchange value is connected to the domination of the general over the particular, of society over its captive membership' (Adorno 1972: 13-14; Adorno 1989: 271; translation amended).

${ }^{10}$ The Frankfurt Institute research focussed on the (more or less repressive) socialization of children in the family rather than the oppression of women, but the general conclusion concerning the role of 'the family' seems transferable. 
${ }^{11}$ Gunnarsson (2015) argues for 'dialecticizing intersectionality' from the perspective of 'dialectical critical realism'.

${ }^{12}$ This notion brings 'intersectionality' - via Critical Theory - back to Simmel's concept of 'the intersection of social circles' as constitutive of modern individuality (Simmel 1992; Stoetzler 2016). Simmel saw multiple intersectionality as a positive achievement of modernity, Black Feminists pointed specifically to the intersections of oppressions, whereas a Critical Theory-version of intersectionality would look forward to a future festival of intersectional diversity following the death of present society's negative totality.

${ }^{13}$ The intersectional approach and Critical Theory have never been entirely alien to each other, in the first place. Collins mentions for example that her undergraduate training in sociology at Brandeis (where Marcuse had taught and where also Angela Davis had studied) was grounded in 'continental philosophy, especially critical theory as advanced by the Frankfurt School' (Collins 2012: 17).

${ }^{14}$ I have made a similar argument for the importance of the category of society in a critique of Judith Butler (Stoetzler 2005). 